ScIDice

\section{Evaluation Of Tooth Discolouration Following The Use Of Silver Nanoparticle Based Intracanal Medicaments - An In Vitro Study}

International Journal of Dentistry and Oral Science (IJDOS)

ISSN: 2377-8075

Research Article

KrishnaKanth Jaju ${ }^{1}$, Iffat Nasim $^{2 *}$

${ }^{1}$ Department of Conservative Dentistry and Endodontics, Saveetha Dental College, Saveetha Institute of Medical and Technical Sciences, Saveetha University, Chennai, India.

${ }^{2}$ Professor and HOD, Department of Conservative and Endodontics, Saveetha Dental College, Saveetha Institute of Medical and Technical Sciences, Saveetha University, Chennai, Tamil Nadu, India.

\title{
Abstract
}

Introduction: Optimal antibacterial efficacy of intracanal medicaments containing combinations of calcium hydroxide and silver nanoparticles has been well documented. However, concerns remain regarding the effect of silver based nanoparticles on tooth color. This study aimed to assess the effects of silver nanoparticles based intracanal medicaments on tooth color. Material And Methods: Fifty extracted single-rooted,single-canal human teeth with straight roots, no caries, no cracks or fractures were collected and assessed. After cleaning and shaping of the root canals, the teeth were randomly divided into two experimental groups $(n=20)$ Group A- Medicament prepared by combination of Calcium hydroxide and silver nanoparticles ,Group B- Medicament prepared by combination of Graphene oxide and silver nanoparticles and a control group of saline $(\mathrm{n}=10)$. After cleaning and shaping experimental groups were randomly divided into two equal groups and assigned medicament was applied below the cemento enamel junction (CEJ).The samples were incubated at $37^{\circ} \mathrm{C}$ and $100 \%$ humidity for one month. Color change $(\Delta \mathrm{E})$ was assessed using a spectrophotometer based on CIELAB system at four time intervals. T0Before medicaments application, T1-Immediately after medicaments placement ,T2-After two weeks, T3-After one month. Data were analyzed using two-way and three-way ANOVA.

Results: There was no statistically significant differences in both the groups at baseline (T0) and after 15 days (T2) ( $\mathrm{p}=0.775$ and $p=0.391$, respectively).But there was a statistically significant difference between baseline (T0) and 1 month (T3) $(p=0.037)$ in both the groups.

Conclusion: Both the tested intracanal medicaments caused tooth discolouration after a time period of one month. So its use must be limited to the root canal space only. Placement of intracanal medicament should be restricted for less than 15 days.

Keywords: Silver Nanoparticles; Cielab; Graphene; Spectrophotometry; Intracanal Medicament.

\section{Introduction}

Microorganisms are the main etiologic factors for the pulp and periapical diseases; therefore, the aim of endodontic treatment is complete elimination of microorganisms from the root canal system[1]. Studies have shown that cleaning and shaping of the root canal system in association with appropriate irrigation solutions do not decrease the microbial load due to presence of microorganism in inaccessible areas in the complex root canal system[2].

Enterococcus faecalis (E. faecalis) is the most resistant bacterial species that remains within the root canal system, It increases the failure rate of the root canal treatment[3]. The main reasons for using intracanal medicament is to prevent inter appointment bacterial proliferation and complete elimination of intracanal bacteria and accelerate recovery of periapical tissues $[3,4]$. The most commonly used intracanal medicament is calcium hydroxide $(\mathrm{Ca}$ $(\mathrm{OH}) 2$ ) and triple antibiotic paste, commonly used intracanal irrigant is chlorhexidine ( $\mathrm{CHX})$ and sodium hypochlorite [3-5]. The efficacy of each intracanal medicament, irrigants can be influenced by many factors such as serum proteins, collagen, $\mathrm{pH}$ and dentin etc. Majority of studies have shown that conventional root

*Corresponding Author:

Iffat Nasim

Professor and HOD, Department of Conservative and Endodontics, Saveetha Dental College, Saveetha Institute of Medical and Technical Sciences, Saveetha University, Chennai, Tamil Nadu, India.

E-mail: iffatnasim@saveetha.com

Received: May 04, 2021

Accepted: July 09, 2021

Published: July 15, 2021

Citation: KrishnaKanth Jaju, Iffat Nasim. Evaluation Of Tooth Discolouration Following The Use Of Silver Nanoparticle Based Intracanal Medicaments - An In Vitro Study Int J Dentistry Oral Sci. 2021;8(6):3214-3218. doi: http://dx.doi.org/10.19070/2377-8075-21000655

Copyright: Iffat Nasim ${ }^{2} 221$. This is an open-access article distributed under the terms of the Creative Commons Attribution License, which permits unrestricted use, distribution and reproduction in any medium, provided the original author and source are credited. 
canal disinfectants are unable to eradicate E. faecalis from the root canal space[3-6].

Recently, nanoparticles (diameter $\leq 100 \mathrm{~nm}$ ) have gained popularity as antimicrobial agents[7]. Their greater surface area and charge density result in their greater interaction with the bacteria. Because of the novel physical and chemical properties of nanoparticles, recent studies have focused on using them for root canal disinfection[8]. The advantage of the use of nanotechnology is an increase in the surface-to-volume ratio of the materials, which increases the solubility, chemical activity and antibacterial efficacy of these agents as intracanal medicaments[8,9]. In endodontics, nanoparticles have been used as irrigants, intracanal medicaments or root canal sealers. Some of the materials which have exhibited improved properties with the application of nanotechnology are nanoparticles of zinc oxide, calcium hydroxide and silver[8-10].

The antibacterial properties of silver depend on silver concentration, release rate and its ability to bind to specific thiol groups containing sulfur and hydrogen in bacterial structures. The results of various studies have shown the superiority of silver based nanoparticles in terms of its biocompatibility[8-12].

Javidi et al. and Afkhami et al. highlighted the potential application of Ag-NPs mixed with calcium hydroxide as a root canal medicament[13]; however, despite the efficacy of Ag- NPs for root canal disinfection, their possible adverse effects such as tooth discoloration made them a controversial agent for in vivo usage especially for long term applications as a root canal medicament[13,14]. Previous studies have shown gray-black discolorations persistent to the crown due to the application of silver point as root canal filling material[13-15]. In addition, continuous release of silver ions resulted in recurrence of discoloration. Therefore, it may be speculated that Ag-NPs may have the same effect with respect to tooth discoloration[13-16].

Thus the question that arises from these experimental studies is whether the use of silver based nanoparticles as an intracanal medicament would result in tooth color change. Considering the gap of information on tooth discoloration due to the application of silver based nanoparticles, this study sought to assess the effect of novel silver based nanoparticles on tooth color.

Previously our team has a rich experience in working on various research projects across multiple disciplines [17-31] Now the growing trend in this area motivated us to pursue this project.

\section{Material And Methods}

\section{Sample Preparation}

The study protocol was approved by the institutional ethical committee.Fifty recently extracted single-canal human anterior teeth with straight roots, $22 \pm 1 \mathrm{~mm}$ length, closed apices, no caries, cracks, fractures, restorations or resorption were included in this study. Presence of a single canal was ensured radiographically. Calculus and stains were removed by a scaler followed by the use of pumice paste and a polishing cup with a low-speed handpiece.

Standard straight-line access cavities were prepared using a round bur (DentsplyMaillefer, Ballaigues, Swit- zerland) and a fissure bur (DentsplyMaillefer, Ballaigues, Swit- zerland). A \#15 K-file (Dentsply, Maillefer, Ballaigues, Switzerland) was introduced into the canal until its tip was visible at the apex and the working length was determined one millimeter short of this length. Each canal was prepared using ProTaper rotary system (DentsplyMaillefer, Ballaigues, Switzerland) and Dentsply X-smart plus motor (DentsplyMaillefer, Ballaigues, Switzerland) according to the manufacturer's instructions (S1, S2, F1- F3).

RC-Prep (Premier Dental Products, Norristown, PA, USA) was used as lubricant and $10 \mathrm{~mL}$ of $2.5 \%$ sodium hypochlorite $(\mathrm{NaO}$ $\mathrm{Cl}$ ) was used as irrigant during root canal preparation. A final rinse with $3 \mathrm{~mL}$ of $17 \%$ ethylenediaminetetraacetic acid (EDTA) and $5.25 \% \mathrm{NaOCl}$ was carried out for five minutes for smear layer removal. Each canal was then rinsed with $5 \mathrm{~mL}$ saline and dried with paper points. To prevent leakage of materials through the apex, the apices of all the teeth were sealed with self-cure glass ionomer (GC Dental, Tokyo, Japan).

Apical two-thirds of the roots were mounted in acrylic resin. The samples were randomly assigned to three groups:

Group A ( $n=20)$ : Medicament prepared by combination of Calcium hydroxide and silver nanoparticles.

Group B - Medicament prepared by combination of Graphene oxide and silver nanoparticles.

Control group ( $n=10)$ : Root canals were filled with saline.

The medicaments were cautiously applied into the Root canal (below the CEJ); a cotton pellet was placed into the pulp chamber and the access cavity was temporarily restored with Cavit $3 \mathrm{M}$ ESPE, St. Paul, MN, USA). During the experiment, all the teeth were kept in a dark glass container with a piece of cotton covering them. The container was incubated at $37^{\circ} \mathrm{C}$ and $100 \%$ humidity for one month.

\section{Assessment Of Tooth Color}

Tooth color in all groups was analyzed at four time points-Baseline (T0), immediately after medicament placement(T1), Two weeks after medicament placement (T2), one month after medicament placement('T3).

Color assessment was done in a laboratory at $37^{\circ} \mathrm{C}$ temperature. A piece of white non-fluorescent leneta paper was used as the background as recommended by the manufacturer. Samples were fixed on a jig. Collimated light source (tungsten) illuminated the tooth surface at $45^{\circ}$ angle relative to the vertical axis, and the spectrophotometer (CS-2000, Konica Minolta, Japan) was adjusted at $0^{\circ}$ angle relative to the vertical axis at $70 \mathrm{~cm}$ distance from the tooth surface with $0.1^{\circ}$ viewing angle. This adjustment created a circular measurement area with an approximate diameter of $1.2 \mathrm{~mm}$ at the center of samples. The spectrophotometer was calibrated prior to measurement of each sample and color of each sample was measured in triplicate at the center of the marked square and the mean of measured values was calculated and reported.

Color coordinates were calculated using D $65 / 2^{\circ}$ viewing condition in CS-S10W software. This viewing condition is commonly used in aesthetic dentistry assays. The CIELAB color space was 
used for the analysis. Other colorimetric data including chroma $\left(C^{*}\right)$, hue angle and tristimulus values were also reported by the aforementioned software. Color differences were calculated using CIELAB 1976. After obtaining the , $\mathrm{L}^{*} \mathrm{a}^{*}$ and $\mathrm{b}^{*}$ parameters, $\Delta \mathrm{L}^{*} \Delta \mathrm{a}^{*}$, and $\Delta \mathrm{b}^{*}$ were calculated. Color differences $\left(\Delta \mathrm{E}^{*}\right)$ was calculated using the following equation -

$\Delta \mathrm{E}^{*}=\sqrt{ } \Delta \mathrm{L} * 2+\Delta \mathrm{a} * 2+\Delta \mathrm{b} * 2$

Data were analyzed using two-way and three-way ANOVA. Post hoc ANOVA was applied whenever required. The level of statistical significance was set at $5 \%$.

\section{Results And Discussion}

Mean of $\Delta \mathrm{E}^{*}, \Delta \mathrm{L}^{*}, \Delta \mathrm{a}^{*}$ and $\Delta \mathrm{b}^{*}$ values for all groups are represented in tables $1-3$, respectively.".

There were no statistically significant differences in both the groups at baseline (T0) and after 15 days (T2) ( $\mathrm{p}=0.775$ and $\mathrm{p}=0.391$, respectively). But there was a statistically significant difference between baseline (T0) and 1 month (T3) ( $\mathrm{p}=0.037)$.

Tooth color can be assessed using several techniques and visual inspection is among the most commonly used techniques. Several standard methods are available for visual inspection of tooth color[32]. In the simplest technique, the specimen and a standard shade guide or the Munsell color chips are compared by the same observer under the same standard light source[32,33]. However, color perception is variable among different individuals and even in the same person at different time points; thus, this technique is associated with errors[32-34]. In addition, the color spectrum of these shade guides is limited. Use of colorimetric devices seems to be more accurate[35]. Devices used for this purpose are divided into two main groups of colorimeters, which determine the three color coordinates and are not very reliable and spectrophotometers, which measure the transmitted or reflected light and determine the color parameters via the use of mathematical formulations[36]. Color assessment by these devices eliminates the subjective errors of color analysis. Spectrophotometry is commonly used for measurement of transmitted or reflected light and is suitable for color analysis of convex and asymmetric objects like teeth[36,37]. Spectrophotometers are the reference tools for color assessment and are superior to other techniques for dental applications [36-38]]. In the current study, CS2000 Konica Minolta spectrophotometer was used for color assessment of tooth crowns. Also, the CIELAB color space was applied for assessment of discoloration of teeth. The $\mathrm{L}^{*}, \mathrm{a}^{*}$ and $\mathrm{b}^{*}$ parameters stand for brightness, red-green axis and yellow- blue axis, respectively[36-39]. This system measures color as a numerical value and shows the overall color change or $\Delta \mathrm{E}$ as a scalar value. Since the mean colorimetric coordinates at baseline are different among groups, statistical analysis of these values results in incorrect interpretation of changes[36-40]. Thus, $\Delta \mathrm{E}^{*}, \Delta \mathrm{L}^{*}, \Delta \mathrm{a}^{*}, \Delta \mathrm{b}^{*}$ and are calculated since they are more reliable for assessment of changes at each time point; therefore, this system was used in this study. The smear layer is composed of microcrystalline and organic debris and covers the root canal walls after root canal instrumentation. Presence of smear layer affects dentin permeability and subsequently the tooth color change[41]. Presence of smear layer decreases tooth discoloration. Under these conditions, longer time is required for the discoloration to occur[41,42]. The smear layer was eliminated in the current study in order to eliminate its effect on the results and to allow better penetration of medicaments into dentinal tubules. In endodontics medicaments are used in between treatment session for necrotic teeth, revascularization

Table 1: Mean of $\Delta \mathrm{L}^{*}, \Delta \mathrm{b}^{*}$ and $\Delta \mathrm{a}^{*}$ values for all groups.

\begin{tabular}{|l|l|l|l|l|l|l|l|l|l|l|l|l|}
\hline Groups & \multicolumn{4}{|c|}{ L value } & \multicolumn{4}{c|}{ A value } & \multicolumn{3}{c|}{ B value } \\
\hline & $\begin{array}{l}\text { Pre } \\
\text { op }\end{array}$ & $\begin{array}{l}\text { Immediate } \\
\text { Post } \\
\text { op }\end{array}$ & $\begin{array}{l}15 \\
\text { days }\end{array}$ & $\begin{array}{l}1 \\
\text { month }\end{array}$ & $\begin{array}{l}\text { Pre } \\
\text { op }\end{array}$ & $\begin{array}{l}\text { Immediate } \\
\text { Post } \\
\text { op }\end{array}$ & $\begin{array}{l}15 \\
\text { days }\end{array}$ & $\begin{array}{l}1 \\
\text { month }\end{array}$ & $\begin{array}{l}\text { Pre } \\
\text { op }\end{array}$ & $\begin{array}{l}\text { Immediate } \\
\text { Post op }\end{array}$ & $\begin{array}{l}15 \\
\text { days }\end{array}$ & $\begin{array}{l}1 \\
\text { month }\end{array}$ \\
\hline $\mathrm{Ca}(\mathrm{OH}) 2+\mathrm{Ag}$ & 86.9 & 87.5 & 88.9 & 90.8 & 1.7 & 2.6 & 3.6 & 4.1 & 23.2 & 24.4 & 24.9 & 25.3 \\
\hline $\mathrm{Go}+\mathrm{Ag}$ & 88.2 & 89.5 & 90.7 & 91.6 & 2.9 & 3.9 & 4.4 & 5.6 & 25.4 & 25.6 & 25.8 & 26 \\
\hline
\end{tabular}

Table 2: Mean of $\Delta \mathrm{E}^{*}$ values for all groups

\begin{tabular}{|l|l|l|l|}
\hline \multicolumn{4}{|c|}{$\Delta$ E Value } \\
\hline Groups & Immediate Post Op & 15 days & 1 month \\
\hline A- $\mathrm{Ca}(\mathrm{OH}) 2+\mathrm{Ag}$ & 1.61 & 3.24 & 5.03 \\
\hline B- $\mathrm{Go}+\mathrm{Ag}$ & 1.65 & 2.92 & 4.38 \\
\hline
\end{tabular}

Table 3: There were no statistically significant differences in both the groups at baseline (T0) and after 15 days (T2) $(p=0.775$ and $p=0.391$, respectively).But there was a statistically significant difference between baseline (T0) and 1 month (T3) $(\mathrm{p}=0.037)$.

\begin{tabular}{|c|c|c|c|c|c|c|}
\hline \multicolumn{7}{|c|}{ ANOVA } \\
\hline & & $\begin{array}{l}\text { Sum of } \\
\text { Squares }\end{array}$ & df & $\begin{array}{c}\text { Mean } \\
\text { Square }\end{array}$ & $F$ & Sig. \\
\hline $\begin{array}{l}\text { IMMEDIATE } \\
\text { POST OP }\end{array}$ & $\begin{array}{l}\text { Between } \\
\text { Groups } \\
\text { Within Groups } \\
\text { Total }\end{array}$ & $\begin{array}{l}.004 \\
.183 \\
.187 \\
\end{array}$ & $\begin{array}{l}1 \\
4 \\
5\end{array}$ & $\begin{array}{l}.004 \\
.046\end{array}$ & .093 & .775 \\
\hline \begin{tabular}{|l} 
AFTER 2 \\
WEEKS
\end{tabular} & $\begin{array}{l}\text { Between } \\
\text { Groups } \\
\text { Within Groups } \\
\text { Total } \\
\end{array}$ & $\begin{array}{l}.141 \\
.611 \\
.752 \\
\end{array}$ & $\begin{array}{l}1 \\
4 \\
5 \\
\end{array}$ & $\begin{array}{l}.141 \\
.153\end{array}$ & .924 & .391 \\
\hline \begin{tabular}{|l|} 
AFTER 1 \\
MONTH
\end{tabular} & $\begin{array}{l}\text { Between } \\
\text { Groups } \\
\text { Within Groups } \\
\text { Total }\end{array}$ & $\begin{array}{r}1.092 \\
.461 \\
1.554\end{array}$ & $\begin{array}{l}1 \\
4 \\
5\end{array}$ & $\begin{array}{r}1.092 \\
.115\end{array}$ & 9.471 & .037 \\
\hline
\end{tabular}


and apexification treatments[43]. Thus, in the current study, we assessed the effects of medicaments on tooth color after variable time intervals to assess tooth discoloration following the short term and long term applications of medicaments.

Calcium hydroxide is used in different forms in endodontic procedures. For greater efficacy, it may be used in conjunction with some other materials such as Ag-NPs, which have shown promising results for efficient elimination of microorganisms from the root canal system[44,45]. Graphene is a carbon based flat monolayer arranged in a two dimensional hexagonal structure. It has distinguished mechanical, electrochemical and physical properties[46]. The graphene family nanomaterials has several graphene derivatives, such as Few-Layered Graphene (FLG), ultrathin graphite, Graphene Oxide (GO), reduced Graphene Oxide (rGO) and graphene nanosheets. It has a remarkable antibacterial ability against both Gram-negative and Gram-positive bacteria as studied by various researchers[47]. Graphene acts as a nano-knife, penetrates and cuts cell membranes of bacteria, induces mechanical stress, extracts phospholipids from lipid membranes and produces oxidative stress through ROS generation and by charge transfer phenomena [48]. However, some concerns exist regarding their potential to cause tooth discoloration. This issue must be cleared prior to clinical application of this agent.

In a clinical trial conducted by Day et al., application of Ultracal XS CH medicament in replanted teeth caused significant darkening of teeth in the clinical setting[49]; however, this color change only caused concerns in a few people. Their results were in line with our findings. Akcay et al. reported no significant color change in teeth due to the application of calcium hydroxide medicament (no significant difference with controls). Such variability in results may be attributed to different medicaments used since they applied calcium hydroxide mixed with distilled water, which has a different composition than graphene based silver nanoparticles used in our study[49,50]. Moreover, their experiment was conducted on bovine teeth; whereas, we used freshly extracted human teeth to better simulate the clinical setting. Similarly, Kim et al. showed tooth discoloration is due to the application of medicament to the access cavity and thus, recommended that application of medicaments must be limited to the root canal space[49-51].

In the current study tooth discolouration was seen in both the tested intracanal medicament, long-term application of both the tested intracanal medicaments caused significant change in tooth color. However, the medicament containing combination of graphene oxide and silver nanoparticles caused less tooth discolouration as compared to the medicament containing combination of calcium hydroxide and silver nanoparticles.

Our institution is passionate about high quality evidence based research and has excelled in various fields[52-62].

\section{Conclusions}

Within the limitations of present study, the following conclusions were drawn: Materials used as intracanal medicaments have the potential to change the tooth color. So, use of intracanal medicaments should be restricted for less than 15 days. Esthetic considerations must be taken into account as well as functional properties and therapeutic efficacy while selecting an intracanal medicament particularly for the anterior teeth. Combination of graphene oxide and silver nanoparticles caused less tooth discolouration as compared to the medicament containing combination of calcium hydroxide and silver nanoparticles.However, application of the intracanal medicament must be confined to the root canal and the residues in the pulp chamber must be carefully removed before restoring the crown.

\section{Acknowledgement}

None. No funding to declare.

\section{References}

[1]. Goldberg M. Root Canal Treatment (RCT): From Traditional Endodontic Therapies to Innovating Pulp Regeneration. J Dent Oral Disord Ther. 2016;4(2):1-6.

[2]. Mathur P, Mathur S. Cleaning and Shaping of the Root Canal System: (Step-back and Crown-down Techniques of Root Canal Preparation) [Internet]. Handbook of Clinical Endodontics. 2008;p. 110-110.

[3]. Alghamdi F, Shakir M. The Influence of Enterococcus faecalis as a Dental Root Canal Pathogen on Endodontic Treatment: A Systematic Review. Cureus. 2020 Mar 13;12(3):e7257. Pubmed PMID: 32292671.

[4]. Kala M, AR S. Comparision of Healing of Periapical Lesion with Different Intracanal Medicament Using Mineral Trioxide Aggregate as Apical Barrier.

[5]. Prasad LK, Tanwar BS, Kumar KN. Comparison of calcium hydroxide and triple antibiotic paste as intracanal medicament in emergency pain reduction: in vivo study. Int J Care Res. 2016;4:244-6.

[6]. Rana M, Jain V, Kaur P, Jalan P, Kapadia JM, Shaikh I. Assessment of Impact of Various Root Canal Irrigants on the Adherence of the Gelatinase-producing and the Gelatinase-deficient E. faecalis Strains to Dentin. J Contemp Dent Pract. 2019 Jan 1;20(1):46-50. Pubmed PMID: 31102394

[7]. Basiruddin SK, Maity AR, Jana NR. Glucose/galactose/dextran-functionalized quantum dots, iron oxide and doped semiconductor nanoparticles with< $100 \mathrm{~nm}$ hydrodynamic diameter. RSC advances. 2012;2(31):1191521.

[8]. Kishen A, editor. Nanotechnology in endodontics: current and potential clinical applications. Springer; 2015 Mar 18.

[9]. Mittal R, Tandan M, Sukul S. Comparative Evaluation of Antibacterial Efficacy of Three Intracanal Medicaments in Primary Endodontic Infections: A Randomized Clinical Trial [Internet]. Vol. 5, Conservative Dentistry and Endodontic Journal. 2020;p. 5-10.

[10]. Ozkocak I, Sonat B. Evaluation of Effects on the Adhesion of Various Root Canal Sealers after Er:YAG Laser and Irrigants Are Used on the Dentin Surface. J Endod. 2015 Aug;41(8):1331-6. Pubmed PMID: 25892511.

[11]. Spielman-Sun E, Zaikova T, Dankovich T, Yun J, Ryan M, Hutchison JE, et al. Effect of silver concentration and chemical transformations on release and antibacterial efficacy in silver-containing textiles. NanoImpact. $2018 \mathrm{Ju}$ 1;11:51-7.

[12]. Tang Y, He W, Wang S, Tao Z, Cheng L. New insight into the size-controlled synthesis of silver nanoparticles and its superiority in room temperature sintering. CrystEngComm. 2014;16(21):4431-40.

[13]. Sofiani E, Wahyuningrum H. Differential effectiveness of calcium hydroxide with $2 \%$ chlorhexidine digluconate and $25 \%$ propolis as a root canal medicament against Enterococcus faecalis (In vitro). Scientific Dental Journal. 2021 Jan 1;5(1):37.

[14]. Kishen A, Shrestha A, Cohenca N. 14 Emerging Technologies in Root Canal Disinfection. Disinfection of Root Canal Systems. 2014:277.

[15]. Panov V. Elimination of root canal filling material from the root and the bone [Internet]. Vol. 6, Journal of Medical and Dental Practice. 2019;9p. 1058-64.

[16]. Greenwall L. Discoloration of Teeth [Internet]. Tooth Whitening Techniques. 2017;p. 1-19.

[17]. Govindaraju L, Gurunathan D. Effectiveness of Chewable Tooth Brush in Children-A Prospective Clinical Study. J Clin Diagn Res. 2017 Mar;11(3):ZC31-ZC34. Pubmed PMID: 28511505.

[18]. Christabel A, Anantanarayanan P, Subash P, Soh CL, Ramanathan M, Muthusekhar MR, et al. Comparison of pterygomaxillary dysjunction with tuberosity separation in isolated Le Fort I osteotomies: a prospective, multi-centre, triple-blind, randomized controlled trial. Int J Oral Maxillofac Surg. 2016 Feb;45(2):180-5. Pubmed PMID: 26338075.

[19]. Soh CL, Narayanan V. Quality of life assessment in patients with dentofacial deformity undergoing orthognathic surgery--a systematic review. Int J Oral 
Maxillofac Surg. 2013 Aug;42(8):974-80. Pubmed PMID: 23702370.

[20]. Mehta M, Deeksha, Tewari D, Gupta G, Awasthi R, Singh H, et al. Oligonucleotide therapy: An emerging focus area for drug delivery in chronic inflammatory respiratory diseases. (2019) Chem Biol Interact. Aug 1;308:206-15.

[21]. Ezhilarasan D, Apoorva VS, Ashok Vardhan N. Syzygium cumini extract induced reactive oxygen species-mediated apoptosis in human oral squamous carcinoma cells. J Oral Pathol Med. 2019 Feb;48(2):115-121. Pubmed PMID: 30451321.

[22]. Campeau PM, Kasperaviciute D, Lu JT, Burrage LC, Kim C, Hori M, et al. The genetic basis of DOORS syndrome: an exome-sequencing study. Lancet Neurol. 2014 Jan;13(1):44-58. Pubmed PMID: 24291220.

[23]. Kumar S, Sneha S. Knowledge and awareness regarding antibiotic prophylaxis for infective endocarditis among undergraduate dental students. Asian Journal of Pharmaceutical and Clinical Research. 2016;154

[24]. Christabel SL, Gurunathan D. Prevalence of type of frenal attachment and morphology of frenum in children, Chennai, Tamil Nadu. World J Dent. 2015 Oct;6(4):203-7.

[25]. Kumar S, Rahman RE. Knowledge, awareness, and practices regarding biomedical waste management among undergraduate dental students. Asian Journal of Pharmaceutical and Clinical Research. 2017;10(8):341.

[26]. Sridharan G, Ramani P, Patankar S. Serum metabolomics in oral leukoplakia and oral squamous cell carcinoma. J Cancer Res Ther. 2017 JulSep;13(3):556-561. Pubmed PMID: 28862226.

[27]. Ramesh A, Varghese SS, Doraiswamy JN, Malaiappan S. Herbs as an antioxidant arsenal for periodontal diseases. J Intercult Ethnopharmacol. 2016 Jan 27;5(1):92-6. Pubmed PMID: 27069730.

[28]. Thamaraiselvan M, Elavarasu S, Thangakumaran S, Gadagi JS, Arthie T. Comparative clinical evaluation of coronally advanced flap with or without platelet rich fibrin membrane in the treatment of isolated gingival recession. J Indian Soc Periodontol. 2015 Jan-Feb;19(1):66-71. Pubmed PMID: 25810596

[29]. Thangaraj SV, Shyamsundar V, Krishnamurthy A, Ramani P, Ganesan K, Muthuswami M, et al. Molecular Portrait of Oral Tongue Squamous Cell Carcinoma Shown by Integrative Meta-Analysis of Expression Profiles with Validations. PLoS One. 2016 Jun 9;11(6):e0156582. Pubmed PMID: 27280700 .

[30]. Ponnulakshmi R, Shyamaladevi B, Vijayalakshmi P, Selvaraj J. In silico and in vivo analysis to identify the antidiabetic activity of beta sitosterol in adipose tissue of high fat diet and sucrose induced type- 2 diabetic experimental rats. Toxicol Mech Methods. 2019 May;29(4):276-290. Pubmed PMID: 30461321.

[31]. Ramakrishnan M, Bhurki M. Fluoride, Fluoridated Toothpaste Efficacy And Its Safety In Children-Review. International Journal of Pharmaceutical Research. 2018 Oct 1;10(04):109-14.

[32]. Liang B, Wallace AM, Trucco E. Visual classification of materials using the Stokes vector. InPolarization and Color Techniques in Industrial Inspection 1999 Sep 16 (Vol. 3826, pp. 224-233). International Society for Optics and Photonics.

[33]. Indow T, Romney AK. Reflectance spectra of Munsell standard chips and their appearance. Color Research \& Application: Endorsed by Inter-Society Color Council, The Colour Group (Great Britain), Canadian Society for Color, Color Science Association of Japan, Dutch Society for the Study of Color, The Swedish Colour Centre Foundation, Colour Society of Australia, Centre Français de la Couleur. 2008 Jun;33(3):229-37.

[34]. Medeiros JA, Pecho OE, Pérez MM, Carrillo-Pérez F, Herrera LJ, Della Bona A. Influence of background color on color perception in dentistry. J Dent. 2021 May;108:103640. Pubmed PMID: 33757865.

[35]. Browning WD. Use of shade guides for color measurement in tooth-bleaching studies. J Esthet Restor Dent. 2003;15 Suppl 1:S13-20. Pubmed PMID: 15000900 .

[36]. Frazer SC. A Self-Emptying Cell for Colorimeters and Spectrophotometers. Proceedings of the Association of Clinical Biochemists. 1962 Aug;2(3):63-4.

[37]. Xu Z, Brill MH. Correction of second-order-diffraction errors in spectrophotometry. Color Research \& Application. 2017 Apr;42(2):189-92.

[38]. Omari M, El Hassouni M, Abdelouahad AA, Cherifi H. A statistical reduced-reference method for color image quality assessment. Multimedia Tools and applications. 2015 Oct;74(19):8685-701.

[39]. Seymour J. Why does the CIELAB a* axis point toward magenta instead of red?. Color Research \& Application. 2020 Dec;45(6):1040-54.

[40]. Billmeyer FW. Table of adams chromatic value color coordinates. JOSA. 1963 Nov 1;53(11):1317-.

[41]. Sanabria-Liviac D, Moldauer BI, Garcia-Godoy F, Antonio-Campos A, Casaretto M, Torres-Navarro J, et al. Comparison of the XP-Endo Finisher file system and passive ultrasonic irrigation (PUI) on smear layer removal after root canal instrumentation. J Dent Oral Health. 2017;4:1-7.
[42]. Adl A, Javanmardi S, Abbaszadegan A. Assessment of tooth discoloration induced by biodentine and white mineral trioxide aggregate in the presence of blood. J Conserv Dent. 2019 Mar-Apr;22(2):164-168. Pubmed PMID: 31142987.

[43]. Kuçi A, Alaçam T, Yavaş O, Ergul-Ulger Z, Kayaoglu G. Sealer penetration into dentinal tubules in the presence or absence of smear layer: a confocal laser scanning microscopic study. J Endod. 2014 Oct;40(10):1627-31. Pubmed PMID: 25260735

[44]. Rödig T, Vogel S, Zapf A, Hülsmann M. Efficacy of different irrigants in the removal of calcium hydroxide from root canals. Int Endod J. 2010 Jun;43(6):519-27. Pubmed PMID: 20536580.

[45]. Anis Motiwala M, Badar SB, Ghafoor R. Comparison of Two Different Methods in the Removal of Oil-Based Calcium Hydroxide From Root Canal System: A Triple-Blinded Randomised Clinical Trial. Eur Endod J. 2021 Mar;6(1):38-43. Pubmed PMID: 33907070.

[46]. Ge M, Si C. Mechanical and electronic properties of lateral graphene and hexagonal boron nitride heterostructures. Carbon. 2018 Sep 1;136:286-91.

[47]. Ray SC. Application and uses of graphene oxide and reduced graphene oxide. Applications of graphene and graphene-oxide based nanomaterials. 2015;1.

[48]. Jovanović Z. Effects of Oxidative Stress on the Electrophysiological Function of Neuronal Membranes. Oxidative Stress and Diseases; Lushchak, VI, Gospodaryo, DV, Eds. 2012 Apr 25:337-58.

[49]. Hinckfuss SE, Messer LB. An evidence-based assessment of the clinical guidelines for replanted avulsed teeth. Part I: Timing of pulp extirpation. Dent Traumatol. 2009 Feb;25(1):32-42. Pubmed PMID: 19208008.

[50]. Fuks A, Peretz B, editors. Pediatric endodontics: current concepts in pulp therapy for primary and young permanent teeth.

[51]. Thomas MS. Crown discoloration due to the use of triple antibiotic paste as an endodontic intra-canal medicament. Saudi Endodontic Journal. 2014 Jan 1;4(1):32.

[52]. Vijayashree Priyadharsini J. In silico validation of the non-antibiotic drugs acetaminophen and ibuprofen as antibacterial agents against red complex pathogens. J Periodontol. 2019 Dec;90(12):1441-1448. Pubmed PMID: 31257588.

[53]. J PC, Marimuthu T, C K, Devadoss P, Kumar SM. Prevalence and measurement of anterior loop of the mandibular canal using CBCT: A cross sectional study. Clin Implant Dent Relat Res. 2018 Aug;20(4):531-534. Pubmed PMID: 29624863.

[54]. Ramesh A, Varghese S, Jayakumar ND, Malaiappan S. Comparative estimation of sulfiredoxin levels between chronic periodontitis and healthy patients - A case-control study. J Periodontol. 2018 Oct;89(10):1241-1248. Pubmed PMID: 30044495 .

[55]. Ramadurai N, Gurunathan D, Samuel AV, Subramanian E, Rodrigues SJL. Effectiveness of 2\% Articaine as an anesthetic agent in children: randomized controlled trial. Clin Oral Investig. 2019 Sep;23(9):3543-3550. Pubmed PMID: 30552590.

[56]. Sridharan G, Ramani P, Patankar S, Vijayaraghavan R. Evaluation of salivary metabolomics in oral leukoplakia and oral squamous cell carcinoma. J Oral Pathol Med. 2019 Apr;48(4):299-306. Pubmed PMID: 30714209.

[57]. Ezhilarasan D, Apoorva VS, Ashok Vardhan N. Syzygium cumini extract induced reactive oxygen species-mediated apoptosis in human oral squamous carcinoma cells. J Oral Pathol Med. 2019 Feb;48(2):115-121. Pubmed PMID: 30451321.

[58]. Mathew MG, Samuel SR, Soni AJ, Roopa KB. Evaluation of adhesion of Streptococcus mutans, plaque accumulation on zirconia and stainless steel crowns, and surrounding gingival inflammation in primary molars: randomized controlled trial. Clin Oral Investig. 2020 Sep;24(9):3275-3280. Pubmed PMID: 31955271.

[59]. Samuel SR. Can 5-year-olds sensibly self-report the impact of developmental enamel defects on their quality of life? Int J Paediatr Dent. 2021 Mar;31(2):285-286. Pubmed PMID: 32416620.

[60]. R H, Ramani P, Ramanathan A, R JM, S G, Ramasubramanian A, et al. CYP2 C9 polymorphism among patients with oral squamous cell carcinoma and its role in altering the metabolism of benzo[a]pyrene. Oral Surg Oral Med Oral Pathol Oral Radiol. 2020 Sep;130(3):306-312. Pubmed PMID: 32773350 .

[61]. Chandrasekar R, Chandrasekhar S, Sundari KKS, Ravi P. Development and validation of a formula for objective assessment of cervical vertebral bone age. Prog Orthod. 2020 Oct 12;21(1):38. Pubmed PMID: 33043408.

[62]. Vijayashree Priyadharsini J, Smiline Girija AS, Paramasivam A. In silico analysis of virulence genes in an emerging dental pathogen A. baumannii and related species. Arch Oral Biol. 2018 Oct;94:93-98. Pubmed PMID: 30015217. 